UDK: $314.15 .045(460)$

Pregledni rad

\title{
CONTROLLING IRREGULAR MIGRATION IN THE KINGDOM OF SPAIN
}

\author{
Maria Jose Hurtado ${ }^{1}$ \\ Ana Kojic ${ }^{2}$ \\ Embassy of Spain in Belgrade
}

\begin{abstract}
Summary: This paper follows on the argument that the success of policies combating irregular migration depends on the combination of external fencing activities with the internal fencing and external and internal gate-keeping policies adopted by a country. This paper reviews the main gate-keeping policies adopted by Spain with a view to highlighting whether and how they achieve their intended effects. It also reviews the success of migration control implemented by Spain, one of the Mediterranean borders of the EU, which has been disproportionately affected by irregular crossings at its' land and sea borders compared with other major EU immigrant destinations, which are geographically situated much farther from migration source and transit countries.
\end{abstract}

Keywords: irregular migration, assisted voluntary return, forced return, border management, capacity building, cooperation.

\section{Introduction}

Migration (lat. migratio) means movement, transfer of a large group of inhabitants from one area to another. ${ }^{3}$ The term which describes the current and the largest yet migrations after the World War II is the term "irregular migrations", that is, migrations whose main characteristic is illicit, illegal state border crossing. The term "legal" derives from the word "law". Law usually determines the highest

1 Home Affairs Attache Embassy of Spain.

2 Assistant Attache for Home Affairs.

3 I. Klajn \& M. Šipka (2010). Veliki rečnik stranih reči i izraza, Prometej, Novi Sad, pp.775. 
legal act, apart from the Constitution, or a legal act formally subordinated to the written Constitution. Besides the term "legal" we often use the term "legitimate" which is the synonym of the previously mentioned term. ${ }^{4}$ In this sense illegality is manifested as the crossing of the international border without a valid passport or any other travel document, that is, against the other administrative or otherwise defined terms, established for leaving the country legally. ${ }^{5}$

Reducing irregular migration requires a comprehensive migration policy regime that brings together both border controls and lateral enforcement mechanisms, within a country and outside its borders. In order to better analyze regimes for the control of irregular migration, we can make two sets of distinctions that are useful for understanding policy choices. The first distinction is to be made between external and internal migration policies: external migration policies are those directed at potential migrants outside the regulating state and at the border, while internal migration policies are those which concern migrants who are already inside the nation's borders.

Secondly, irregular migration control policies can be distinguished on the basis of whether they follow a 'fencing' or a 'gate-keeping' strategy: gate-keeping strategies aim at restricting practical legal access to a nation and its institutions, while fencing measures actively target illegal migrants in order to arrest and then expel them. Typically, gate-keeping involves paper controls of people who seek to enter a country or who come voluntarily forward, while fencing involves detecting persons in hiding and trying to stop those who seek to enter without appropriate authorization. ${ }^{6}$

\section{Irregular Migration Policies in Spain}

The first measure designed to regulate immigration in Spain was approved in 1985 in order to adapt Spanish legislation to European policies. At that time, the foreign population in the country barely amounted to 200,000 persons, most of whom were European citizens. The 1985 Law was passed without public debate, approved in the Parliament almost unanimously and only provoked significant reactions in Ceuta and Melilla, the two Spanish towns in North Africa with a high percentage of immigrants of Moroccan origin. The Law was restrictive, mainly directed to facilitate the expulsion of irregular immigrants, making it very difficult to get into Spain through legal channels and renew stay permits. It ruled out, for instance, family reunification, and made no provision for a permanent residency permit. ${ }^{7}$

4 K. D. Mitrović (2004). Teachings of the two major world systems of law on legality and their unification, Journal of Criminalistic and Law, Academy of Criminalistics and Police Studies, no. 2. pp. 137-138.

5 S. Mijalković \& M. Žarković (2012). Ilegalne migracije i trgovina ljudima, Kriminalsitickopolicijska akademija, Beograd, p. 24.

6 D. Vogel, The International Migration Review, Vol. 34, No. 2 (Summer, 2000), pp. 392.

7 Ley Orgánica 7/1985, de 1 de julio, sobre derechos y libertades de los extranjeros en España (Constitutional Law on Rights and Freedoms of Foreigners in Spain). 
In 2000, the second and third laws on immigration were passed, both known as 'Ley de Extranjería' (Law on Foreigners). ${ }^{8}$ They aimed to create a legal framework to pursue the integration of immigrants, and were thus in opposition to the 1985 Law, which mainly focused on controlling their arrival and stay. All these laws were rather generous - in comparison with other European countries' standards - with regard to the social rights of immigrants, be they legal or illegal, or the legal guarantees offered to irregular immigrants.

When the first Law was discussed in the Spanish Parliament, the Popular Party did not hold a sufficient majority and the Law was approved against their will. However, the 2000 general elections granted the Popular Party the majority and the government presented a new version of the Law. The debate around the proposed reform of this Law was the first occasion that immigration became an important public matter in Spain, attracting wide coverage in the media. The Popular Party was alone in its defence of a more restrictive Law, when all other political parties, NGOs, the Catholic Church and trade unions were against the reform. The visibility and media coverage of the debate increased because of the confrontation between members of government, in particular the Minister of Labour who was openly against the reform, and the Minister of Interior who was in favour. The reform of the Law was approved with the votes of the Popular Party only, and it included many small changes. ${ }^{9}$ Public attention focused on two issues: first, the restrictions directed to facilitate the expulsion of illegal immigrants, and second the limitations applied to them in the right of association, strike and demonstration. Compared with the first Law on Foreigners (4/2000), this was a restrictive Law, but not when compared with the 1985 Law or with most European provisions. The granting to all immigrants, irrespective of their legal status, to free access to public medical services in the same basis as Spaniards, and to public education from 3 to 16 years, with the only condition that they register in the Local Padrón, has had special relevance because from then on irregulars register in the Padrón and because this offer of public services became a pull factor.

The Law was modified again in November 2003. This modification was agreed by all the main parties, and was concerned with the intense and unexpected increase of immigrants in the first years of the decade. The reform's main declared objective was to improve the instruments so as to address illegal migration and the trafficking and smuggling of human beings. For instance, the reformed Law allows the Police to access the data collected in the Municipal Registers, oblige international transport enterprises to give notification of passengers who do not use their return ticket, include new penalties for smugglers and enterprises who hire irregular workers, and oblige foreigners without a permanent residence permit to renew their inscription in the Municipal Register every two years ${ }^{10}$.

As regards the policies which we can term proactive and whose declared objective is to adapt the arrival of aliens to the labour market needs and to allow their stay from the beginning in conditions of legality, the two main instruments

8 Ley Orgánica 4/2000 and Ley Orgánica 8/2000 (Constitutional Law).

9 BOE (State Gazette) 23 December 2000, Real Decreto 2392/2004 (Royal Decree) Ley Orgánica 4/2000 and Ley Orgánica 8/2000 (Constitutional Law).

10 BOE (State Gazette) 21 December 2003.

NBP • Journal of Criminalistics and Law [101] 
have been the contingent and the "general regime", both extremely ineffective. The so called general regime was in force until 2001 and permitted the individual contracting of a worker abroad by an employer on condition that "the domestic employment situation" permitted this. ${ }^{11}$

From 2004 on, this catalogue of jobs difficult to cover is the basis for the entry of regular migrants. According to the rule, the employer must apply for the contract of an identified foreign worker and once authorization is obtained, the foreigner must apply in his or her country of origin for the visa. The initial residence and labour permit which receives the foreigner is valid for one year and can be restricted to an economic sector and a province. This initial permit must be renewed twice (each renovation allows two more years of labour and stay permit) until the fifth year, when the renewal produces a permanent permit. In order to renew the permit during these first five years, immigrants must maintain their previous job or show a new contract or a job offer. The frequent failure to comply with this exigency in the period of renewal is an important way from legality to illegality.

As concerns preventive aspects, that is to say, the fight against irregular immigration, after the 2001 regularization the government of the Popular Party proclaimed this fight as its absolute priority in the migratory field. The government of the Socialist Party did the same after the so called "crisis of the cayucos during the summer of 2006, when around 25,000 irregular Sub-Saharan immigrants reached the coasts of the Canary Islands. The components of this defensive policy are the following:

1) Reinforcement of border controls. Spain has made substantial efforts to seal its maritime frontier with Africa, through the creation of the Integrated System of External Surveillance (Sistema Integrado de Vigilancia Exterior, SIVE) provided with powerful technical resources and able to detect virtually all boats which approach the coastline. This system has been very effective at reducing the arrival of Moroccan immigrants. But for many years Morocco did not comply with agreement signed with Spain which obliges it to accept the nationals of third countries who arrive in Spain from the coasts of Morocco. Only since 2004, and due to the pressure from the EU, Morocco collaborates effectively in the prevention of this irregular immigration, and, since 2004 the cayucos leave from farther south, from Mauritania or Senegal bound for the Canary Islands.

2) The most substantial Spanish efforts against illegal immigration have been concentrated on maritime surveillance despite the fact that its statistical weight in the total arrivals of immigrants is very small. However, unlike the others who arrive through airports or by land from France, these have politically relevant characteristics, since they have an extraordinary effect on public opinion because the mass media focus on them, their arrivals are televised live and their voyages are dramatic and often end in death. They also require the humanitarian aid of the State services. In fact, a large part of the work of the Civil Guard involves attending to the immigrants intercepted.

3) Harsher penalties for those involved in trafficking. In 2003, with the transposition of European legislation, a modification was incorporated into the

11 C. González-Enríquez, Undocumented Migration Counting the Uncountable. Data and Trends across Europe, January 2009, p.13 
Penal Code after it was agreed by the main parties. This punishes the trafficking of persons with sentences of 8 to 10 years imprisonment. The reform also included an article which stipulates prison sentences of 6 months to 3 years for those who foster or facilitate the illegal traffic of persons bound for Spain even when this is done with no profit motivation. The reform of the Penal Code also included legal measures to protect the victims of sexual or work exploitation. The victims who collaborate with the police in order to reveal the networks are offered legal residence for one year renewable and they come under a witness protection programme.

4) Labour inspection. The offer of work is the main pull factor attracting immigrants; therefore labour inspection is one of the most effective method against irregular immigration.

5) Strengthening of the police services. In this field, the most important landmark was the creation in 2001 of the UCRIF (Unidad para combatir las redes de inmigracion y falsificación de documentos - Unit for Combating Immigration and Document Falsification Networks), belonging to the Aliens Brigade of the National Police Force. The UCRIF acts on denouncements received and work on prostitution trade as there are very few denouncements regarding illegal employment.

6) Europeanization of the immigration control policy. For years Spain has been demanding greater collaboration from the European Union to control irregular immigration. In this regard, important events were the creation of the European Frontiers Agency (FRONTEX) promoted among others by Spain, the signing of joint agreements for readmission or the organization of joint repatriation flights. From the Spanish perspective the main achievement is the support of the Commission in order to condition the external policies of the EU as regards the origin or transit countries (mainly Morocco), so that they collaborate effectively against their own irregular immigration and immigrants in transit.

\section{Border Control Strategies in Spain}

During the last decade, Spain has been faced with persisting problems related to the management of its borders. The focal points of migration pressures however have shifted somewhat. Thus, for Spain, unlawful entry has become the main challenge for effective policing of the sea borders, with special reference to the Canary Islands. Until 2004, the Moroccan authorities refused to re-admit irregular migrants apprehended at the Spanish border coming from Morocco unless they were its own nationals. However, under pressure from the EU, the Moroccan government accepted to re-admit sub-Saharan Africans to its territory with a view to then returning them to their countries of origin. Morocco also restricted its visa allowances for sub-Saharan African countries under pressure from Spain, so as to reduce transit migration through the country. ${ }^{12}$

12 J. Carling, Migration Control and Migrant Fatalities at the Spanish-African Borders, p. 327, June 2007

NBP • Journal of Criminalistics and Law [103] 
This has had an impact on the border-crossing strategies of people from sub-Saharan Africa who initially left Africa from Mauritania, and later, when Mauritania started to cooperate with the EU/Spanish border forces, from Senegal and the Ivory Coast, using the Canary Islands as a transit point. Indeed, the year 2006 was a 'crisis' year with around 30,000 apprehensions of irregular migrants. ${ }^{13}$

In order to tackle this issue, Spain has managed to sign re-admission agreements with Cape Verde, Mali, Guinea Conakry, Guinea Bissau and Nigeria and varied forms of cooperation agreements with other states in the region, with the result of a notable improvement in border management and hence a notable decrease of irregular arrivals from Africa. Apprehensions of irregular migrants arriving at the Canary Islands have fallen from over 30,000 in 2006 to approximately 12,000 in 2007 , and only 3,600 in $2010 .{ }^{14}$ This decrease is to some extent attributable to the intensification of sea-border patrols and joint FRONTEX operations in the area which led migrants and smugglers to try alternative routes. Out of the many joint FRONTEX operations, it is important to mention, in terms of Spain's participation, the joint operation HERA and the joint operation INDALO.

Joint Operation Hera was the response to an enormous surge in irregular immigration from West Africa to Spain's Canary Islands in the Atlantic Ocean, conducted in the year 2006. Tens of thousands of citizens from countries such as Senegal, Mauritania and Cape Verde, attracted by the prospect of life in Europe and lured by the relative proximity of the Canary Islands, had decided to risk a hazardous sea voyage in ill-equipped open boats known as cayucos. Taking into account the fact that Spain, the EU Member State most affected, had already reached a political agreement with some West African countries to tackle irregular immigration, a rigorous assessment of the situation by the FRONTEX Risk Analysis Unit suggested a two-pronged approach to the problem. On the Canary Islands, Operation Hera would provide support to the Spanish authorities in interviewing the would-be migrants who were fortunate enough to survive the ocean journey and reach the Canaries. At sea, the focus was to be on joint patrols off the western coast of Africa involving personnel and equipment from several EU Member States as well as from Senegal and Mauritania. The close proximity of these joint maritime and airborne patrols to the coast of West Africa was crucial: it meant that the unsafe boats used by the irregular immigrants could be stopped and turned back to safety before the dangerous voyage to the Canary Islands could claim even more lives. The first stage of the operation, known as Hera I, began on 17 July 2006. Experts from France, Germany, Italy, the Netherlands, Norway, Portugal and the United Kingdom flew to the Canary Islands to help Spanish officials cope with the mammoth task of interviewing and assisting the West African survivors. Some migrants had been fortunate enough to reach the islands without serious mishap. Others, stranded and distressed, had been picked up at sea by Operation Hera patrol vessels. Identification of these individuals was of paramount importance. Without knowing who a person was and where he or she had come from, it was impossible to identify genuine asylum seekers who may have been fleeing war or political persecution. Meanwhile, less than a month later, Operation Hera II began. Patrol boats and aircraft from Spain, Portugal and

13 Data from the Ministry of Interior of the Kingdom of Spain.

14 Ibidem. 
Italy (and later Finland) searched the sea between the West African coast and the Canary Islands, turning back irregular immigrants in cayucos near the coast or rescuing those who had managed to go farther and then found themselves lost in the Atlantic Ocean without food or water. The logistics involved in Hera II were daunting: moving personnel and equipment from Europe, adapting operating procedures and machines, and setting up support infrastructure had to be done quickly and efficiently. But the hard work paid off and soon European and African officials were at sea together on each other's vessels. Under this arrangement the authority for returning cayucos setting off from Africa rested with the Senegalese and Mauritanian officials involved in the FRONTEX operation. This combined effort with African authorities had been a test for the first operation to take place in cooperation with a Third Country. Yet despite the complexity of the operation, and the long distance from mainland Europe, it had worked well. The immediate results of Hera were impressive. By the end of October 2006 almost 19,000 irregular immigrants had arrived on the Canary Islands. Yet FRONTEX experts and the Spanish authorities involved in Hera I were able to identify every person. These would-be immigrants and the thousands of others turned back at the West African coast under Hera I. The interviews had another important benefit. As more information was received, verified and analyzed, it was possible to build a picture of the criminal infrastructure which had launched so many vulnerable people on a harsh and dangerous journey. As a result, a number of the unscrupulous 'facilitators' who took money from desperate people unaware of the dangers they faced were arrested.

However, border surveillance and controls would not have been effective if Spain had not managed to enlist the cooperation of Morocco, primarily, and several western African countries further south, in re-admitting their nationals. Thus, while during the period 2002-04 less than one third of the expulsion orders issued were executed, the rate rose to $92 \%$ in $2007 . .^{15}$ Thus, the case of Spain and the recent decrease in irregular migration pressures at the Canary Islands suggests that a global diplomatic approach for cooperation and assistance to source and transit countries is more effective than the intensification of border controls alone. In other words, external fencing needs to be coupled with external gatekeeping in order for either to be effective. ${ }^{16}$

Joint operation INDALO mounted in the year 2014, aimed at implementing coordinated operational activities at the external sea borders of the Western Mediterranean region in order to control irregular migration flows towards the territory of the Member States of the European Union and to tackle cross-border crime. Host country being Spain, while participating countries were Belgium, Denmark, Finland, France, Greece, Italy, Portugal, Romania, Slovakia and Morocco.

15 Data from the Ministry of Interior of the Kingdom of Spain 16 FRONTEX, Publication Beyond the Frontiers, p. 30. 


\section{Actions Undertaken by Spain in Regard to Irregular Immigration Management}

When it comes to the measures and actions Spain is applying in cooperation with the neighbouring countries in regard to tackling the phenomenon of the irregular immigrations, it is of the outmost importance to mention four of them in particular: Border Control, Fight against Human Smuggling Networks, Joint police operations with other countries and Return.

I) Effective Border Control is crucial in terms of controlling the immigration flows, however, in order for such control to give results, it is necessary to conduct it from both sides of border, and it is precisely why, cooperation with third countries is essential. Having that in mind, Spain has developed a series of mechanisms, in cooperation with some of the neighbouring countries, such as Joint Maritime and Land Patrols, Joint Actions, Trainings for Border Police members, Bilateral Agreements and Joint Information Systems for Border Control.

Precisely after the deployment of the SIVE (Sistema Integrado de Vigilancia Exterior) - a sophisticated surveillance electronic mechanism initiated in 1999 and since then expanded to cover the southern coast of Spain and the Gibraltar strait and, more recently, the Canary Islands - and the beginning of effective collaboration with Morocco regarding its nationals, irregular entry from Morocco was greatly reduced, while boats were systematically detected and their passengers returned to Morocco.

This system forms a part of the EUROSUR (European Border Surveillance System), designed to support the Member States in their efforts to reduce the number of illegal immigrants entering the European Union by improving their situational awareness at their external borders and increasing the reaction capability of their information and border control authorities. It focuses on enhancing border surveillance in order to:

- reduce the number of illegal immigrants who enter the European Union undetected;

- reduce the number of deaths of illegal immigrants by saving more lives at sea;

- increase the internal security of the EU as a whole by contributing to the prevention of cross-border crime.

The European Border Surveillance System (EUROSUR) should help the Member States achieve full awareness of the situation at their external borders and enhance the reaction capability of their law enforcement services. "Situational awareness" measures the capability of the authorities to detect cross-border movements and find reasoned grounds for control measures; "reaction capability" measures the lapse of time required to control any cross-border movement and the time and means necessary to react adequately to unusual circumstances.

EUROSUR would provide the common technical framework required to rationalize cooperation and 24-hour communication between the Member States' authorities and foster the use of cutting-edge technologies for border surveillance. One essential operational objective must be to create an information-sharing 
(excluding personal data) environment among national and European systems. ${ }^{17}$

Furthermore, we must not disregard the effects of such projects like Seahorse Atlantic Network, established in 2006, as well as the extension of this cooperation Seahorse Mediterranean Network signed in 2013, which is of particular importance for Spain.

Approved by the European Commission, the project Seahorse Mediterranean Network counts on collaboration with Spain, Italy, France, Malta, Portugal, Cyprus, Greece and Libya. The agreement included the establishment of the Seahorse Mediterranean network, the training of those working in the sector and coast guards and the holding of courses for coast and land border monitoring in Libya and North African countries that join the programme for effective and coordinated efforts against clandestine immigration. The aim is to set up a satellitebased communication network among the countries involved. The project is a continuation of the Seahorse Atlantic programme, which made it possible to diminish migratory pressures via sea from Africa to Europe: a decrease from 31,000 migrants intercepted in 2006 to 332 in $2012 .{ }^{18}$

II) Fight against Human Smuggling Networks is one of the most important issues particularly in terms of police actions. That is why many countries develop training programmes as well as programmes of police cooperation with neighbouring countries. However, another step forward is required as well, and that is to improve the exchange of operational and strategic information, ensuring thus that the police actions will provide effective results, especially in regard to the Fight against Human Smuggling Networks. Some of the effective solutions in achieving the above set goal are setting up National Contact Points and Liaison Officers as well as forming Joint Investigation Teams.

III) When it comes to the Joint police operations, it is important to highlight the factors which make it possible, such as: political understanding, open communication and a daily operational cooperation on the field. In the light of the above said factors, Spain has dedicated much attention to bilateral cooperation, focusing on the establishment of the following mechanisms:

- The creation of Police cooperation centres in which every day representatives of neighbouring Police bodies work side by side, thus enhancing their mutual collaboration and providing effective results.

- Implementation of projects such as Blue Sahel and West Sahel, ${ }^{19}$ which include a variety of police actions, out of which it is most significant to mention land and maritime patrols.

- Specialization of the Police force members.

IV) Last but not least, it is the necessity to develop an efficient return policy of those immigrants who have not obtained their right to asylum, through

17 EURLEX, http://eur-lex.europa.eu/ . aspx (9.12.2015).

18 European Parliament, http://www.europarl.europa.eu/RegData/docs_autres_institutions/ commission_europeenne/comitologie/ros/2012/D023377-01/COM-AC_DR(2012)D02337701(ANN2)_EN.pdf. aspx (5.12.2015).

19 Projects launched under the Rabat process to prevent migration and other risks such as drug trafficking or terrorism, and that includes the creation of border patrols, police training courses, strengthening cooperation with the countries of Sahel. 
assisted voluntary return and forced return, with the use of such mechanisms as an adequate coordination between final destination countries, as well as with those of origin and transit countries, thus creating a destimulating effect with the objective to prevent the irregular use of the migratory routes.

\section{European Initiatives Supported by Spain}

The European Agenda on Migration ${ }^{20}$ views migration management as a shared responsibility not only among the EU Member States but also in terms of nonEU countries of transit and origin of migrants. By combining both internal and external policies, the Agenda provides a new, comprehensive approach grounded on mutual trust and solidarity among the EU Member States and institutions.

Migration is both an opportunity and a challenge for the EU. The medium to long term priorities consist of developing structural actions that look beyond crises and emergencies and help the EU Member States to better manage all aspects of migration. The Agenda is built upon four pillars: ${ }^{21}$

1) Reducing the incentives for irregular migration: the focus is on addressing the root causes behind irregular migration in non-EU countries, dismantling smuggling and trafficking networks and defining actions for the better application of return policies.

2) Saving lives and securing the external borders: this involves better management of the external border, in particular through solidarity towards those Member States that are located at the external borders, and improving the efficiency of border crossings.

3) Strengthening the common asylum policy: with the increases in the flows of asylum seekers, the EU's asylum policies need to be based on solidarity towards those needing international protection as well as among the EU Member States, whose full application of the common rules must be ensured through systematic monitoring.

4) Developing a new policy on legal migration: in view of the future demographic challenges the EU is facing, the new policy needs to focus on attracting workers that the EU economy needs, particularly by facilitating entry and the recognition of qualifications. ${ }^{22}$

In terms of the above mentioned priorities, it is significant to stress that some of the most relevant initiatives related to the migrant crises and supported by Spain were the ones adopted and implemented at the Valletta Summit on migration, held on $11^{\text {th }}$ and $12^{\text {th }}$ November 2015. The Valletta summit on migration brought together European and African Heads of State and Government in an effort to strengthen cooperation and address the current challenges but also the opportunities of migration. It recognized that migration is a shared

20 European Commission, European Agenda on Migration, Brussels, 13.5.2015, $\operatorname{COM}(2015) 240$ final 21 Ibidem.

22 The European Commission, http://ec.europa.eu/dgs/home-affairs/what-we-do/policies/ european-agenda-migration/index_en.htm, aspx. (11.12.2015.). 
responsibility of countries of origin, transit and destination. The EU and Africa worked in a spirit of partnership to find common solutions to challenges of mutual interest.

Leaders participating in the summit adopted a political declaration and an action plan designed to: ${ }^{23}$

- address the root causes of irregular migration and forced displacement

- enhance cooperation on legal migration and mobility

- reinforce the protection of migrants and asylum seekers

- prevent and fight irregular migration, migrant smuggling and trafficking in human beings

- work more closely to improve cooperation on return, readmission and reintegration

They also agreed upon a list of 16 concrete actions to be implemented by the end of 2016. The existing mechanisms of the Rabat Process, the Khartoum Process and the Joint EU-Africa strategy will be used to monitor the implementation of the action plan. The EU Emergency Trust Fund for stability and addressing root causes of irregular migration and displaced persons in Africa was also formally launched at the occasion of the Valletta summit. It aims to provide additional funding to support the implementation of the action plan.

\section{Results of the Measures Applied in Regard to Fighting Irregular Migration in the Kingdom of Spain}

In order to provide an objective conclusion regarding the measures applied in terms of border control, it is necessary to give an analysis of the number of migrants registered by the Spanish police. Since the year 2000 up until the year 2014, 195,458 migrants have been registered in Spain. Said timeframe can be divided into two periods, the first one being from 2000 until 2006, while the second one is from 2006 until 2014. Compared to the beginning of the analyzed period, the results at the end of the period show a reduction of $69.70 \%$. The largest flow of migrants was registered in 2006, while the smallest one was in 2013. With the continuous application of the described measures, the number of migrants in $2014(4,552)$ in comparison to $2006(39,180)$ shows a reduction of $88.38 \%$. However, it is necessary to emphasize that in 2014 as many as $40.6 \%$ more migrants have been detected, in comparison to 2013 (3237).

According to the last published data by the Ministry of Interior of the Kingdom of Spain, which were published in May 2015, the largest flow of irregular migrants was detected in 2006 (Graph 1).

23 The European Council, http://www.consilium.europa.eu/, aspx (10.12.2015).

NBP • Journal of Criminalistics and Law [109] 


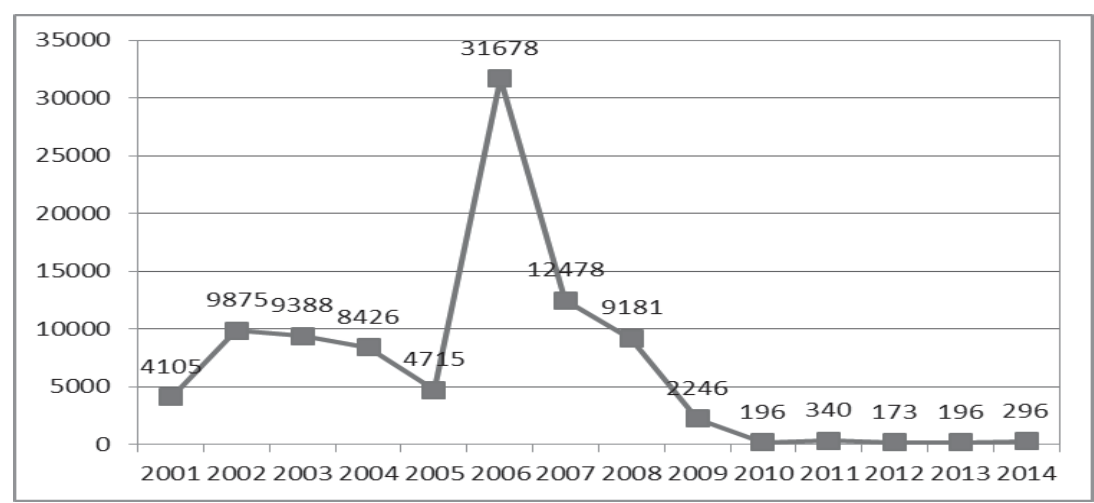

Graph 1: Migrants registered in Spain since 2001 to $2014 .^{24}$

This raise in the number of migrants was mostly detected in the two costal crossing points: the Balearic and the Canary Islands. While in 2006 the number of migrants who entered through the Balearic Islands was 7,502, that number was reduced to 4,256 in 2014 that is by $43 \%$. In the Canary Islands, the number of migrants who entered was 31,687, and was reduced by $99 \%$, to 296 .

A raise in the number of migrants was detected in the summer of 2014, when the number of migrants who arrived to Ceuta and Melilla went up to 7,485, from 4,235 migrants who arrived in the previous year, in 2013 , thus rising by $77 \%$. This particular increase was due to the Syrian war crisis and represented a novelty in terms of irregular migration flows previously detected in Spain.

As shown on the Graph 2, in 2014, around 19,000 attempts to cross the border through Melilla were detected (350\% more than in 2013). However, thanks to the measures applied by the Police forces and the State policies, around $90 \%$ of those attempts were stopped, and have never reached neither Ceuta nor Melilla.

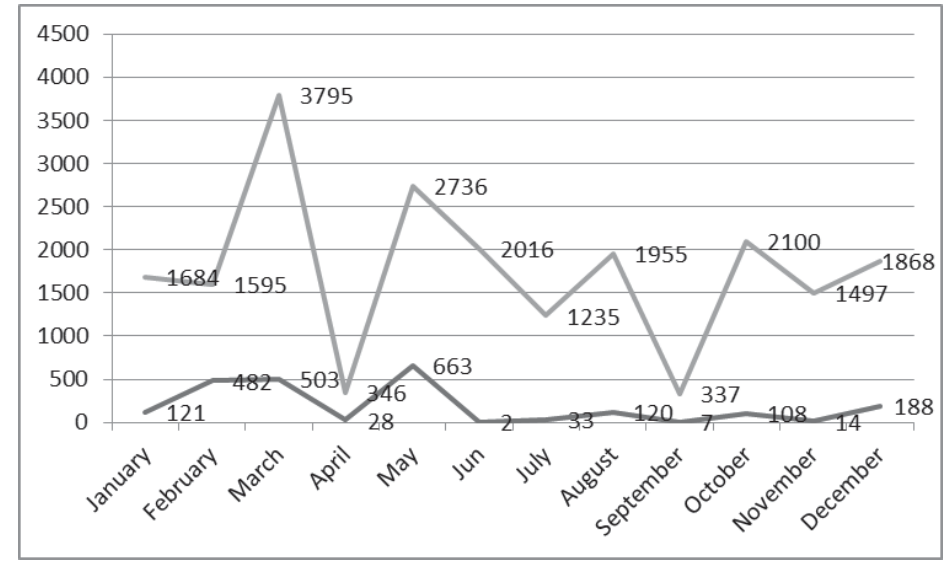

Graph 2: Migrants detected by months in $2014^{25}$

24 Ministry of Interior of the Kingdom of Spain, Balance 2014, Lucha contra la Inmigracion Irregular (2014 Report on fight against irregular migrations) p. 8

25 Ibidem, p.10. 
Analyzing the mayor migratory issues involving Spain, we can see that apart from the costal hot spots, such as Balearic and Canary islands, there is a heavy pressure on its land border of Ceuta and Melilla as well. Adding to the already existing pressure of the African immigrants is the recent flow of Syrians, which contributed, as was shown, to a great increase of migrants in the summer of 2014.

It is for this reason that Spain has paid much attention to action and cooperation between the National Police and the Civil Guard members, its Ministry of Interior is constantly adapting to new tendencies when it comes to fighting human smuggling networks, and as was previously emphasized, one of the crucial thing is by far the tight cooperation with the final destination countries, the transit countries and the countries of origin.

\section{Conclusion}

Immigration means different things to different Member States. But what one state does with its immigration policies affects the rest of the Union, particularly within the Schengen area. This is why at least some degree of harmonization of immigration policies at the European level is necessary. The Spanish action in this respect has been wide-ranging and includes comprehensive measures, ranging from the prevention of would-be irregular migrants in their countries of origin to the return of those who managed to settle irregularly somewhere within the EU. This cooperation in fighting illegal migration has taken the form of harmonization of laws, coordination of operational cooperation, the use of advanced technological instruments and cooperation with third countries. Besides these, Spain cooperates through the sharing of operational information through the networks of Immigration Liaison Officers posted in the sending countries and with the support of Europol, thus tackling a variety of factors. In this way Spain is using the measures at all stages of irregular migratory flows, focusing on prevention, control and deterrence. Summing up, it is important and necessary to take into consideration the importance attached by Spain to the migratory phenomenon and to stress again on the unbending commitment of the Spanish Government to further develop a migratory national policy based on the fight against irregular migration and the eradication of networks trafficking with human lives; the enhancement of administrative services for information and migration management and the promotion and encouragement of the integration of legal immigrants into the Spanish society under the spirit of respect to the State of Law. 


\section{References}

1. Carling, J; Migration Control and Migrant Fatalities at the Spanish-African Borders, June 2007. Eurlex, http://eur-lex.europa.eu/ . aspx (9.12.2015).

2. European Commission, http://ec.europa.eu/dgs/home-affairs/what-we-do/ policies/european-agenda-migration/index_en.htm, aspx. (11.12.2015.).

3. European Council, http://www.consilium.europa.eu/, aspx (10.12.2015).

4. European Parliament, http://www.europarl.europa.eu/RegData/docs_autres institutions/commission_europeenne/comitologie/ros/2012/D023377-01/ COM-AC_DR(2012)D023377-01(ANN2)_EN.pdf. aspx (5.12.2015).

5. Frontex, Publication Beyond the Frontiers.

6. González-Enríquez, C; Undocumented Migration Counting the Uncountable. Data and Trends across Europe, January 2009.

7. Klajn, I; \& Šipka, M; Veliki rečnik stranih reči i izraza, Prometej, Novi Sad, 2010.

8. Ley Orgánica (Constitutional Law on rights and freedoms of foreigners in Spain).

9. Mitrović, K, D; Teachings of the two major world systems of law on legality and their unification, Journal of criminalistic and law, Academy of Criminalistics and Police Studies, n.2., 2004.

10. Mijalković, S; \& Žarković, M; Ilegalne migracije i trgovina ljudima, Kriminalsiticko-policijska akademija, Beograd, 2012.

11. Ministry of Interior of the Kingdom of Spain, Balance 2014, Lucha contra la Inmigracion Irregular ( 2014 Report on fight against irregular migrations)

12. Vogel, D; The International Migration Review, Vol. 34, No. 2, 2000. 


\title{
KONTROLA IREGULARNIH MIGRACIJA U KRALJEVINI ŠPANIJI
}

\author{
Marija Hose Hurtado \\ Ana Kojić \\ Ambasada Španije u Beogradu
}

Sažetak: Ovaj rad nastavlja raspravu da uspeh politika borbe protiv iregularnih migracija zavisi od kombinacije aktivnosti na spoljašnjem i unutrašnjem odbijanju i politikama spoljašnjeg i unutrašnjeg čuvanja granica koje neka zemlja usvoji. Ovaj rad daje pregled glavnih politika za čuvanje granica koje je usvojila Španija uz pregled i isticanje da li i kako se pomoću njih postižu nameravani efekti. Isto tako daje pregled uspeha u kontroli migracija koje primenjuje Španija, jedna od mediteranskih granica EU, koja je neproporcionalno pogodjena iregularnim prelazima svojih granica kako na zemlji tako i na vodi u poredjenju sa ostalim glavnim imigrantskim destinacijama EU, koje su geografski smeštene mnogo dalje od izvora migracija i tranzitnih zemalja. 